\title{
PROFIL PENALARAN MATEMATIKA SISWA SMP DALAM MENYELESAIKAN SOAL TIMSS DITINJAU DARI JENIS KELAMIN
}

\author{
Astrie Karina Putrii Eridani \\ Pendidikan Matematika, Fakultas Matematika dan Ilmu Pengetahuan Alam, Universitas Negeri Surabaya, \\ astrieeridani@mhs.unesa.ac.id \\ Pradnyo Wijayanti \\ Pendidikan Matematika, Fakultas Matematika dan Ilmu Pengetahuan Alam, Universitas Negeri Surabaya, \\ pradnyowijayanti@unesa.ac.id
}

\begin{abstract}
Abstrak
Dalam pembelajaran matematiaka, terdapat tiga aspek yang harus dikuasai oleh siswa, yaitu adalah pemecahan masalah, aspek pemahaman konsep, dan penalaran. Dari ketiga aspek yang telah disebutkan, penalaran adalah salah satu aspek dari tujuan pembelajaran matematika. Dalam TIMSS juga memiliki tiga aspek yang harus dimiliki siswa saat pembelajaran matematika berlangsung, yaitu aspek penerapan (applying), pengetahuan (knowing), dan penalaran (reasoning). Dari situ dapat disimpulkan pentingnya kemampuan penalaran yang harus dimiliki oleh siswa. Kemamapuan penalaran sendiri adalah kemampuan untuk menghubungkan ide yang muncul dalam soal dan menyusunnya dalam suatu argument matematika sehingga dapat menghasilkan prodak berupa jawaban yang bisa di pertanggung jawabkan oleh siswa. Di Indonesia, penalaran matematika dirasa sangat lemah bagi kemampuan anak, hal ini berdasarkan tes yang dilakukan oleh TIMSS. Penelitian yang dilakukan dalam jurnal ini adalah penelitian deskriptif kualitatif. Penelitian dilakukan di SMP SHALAHUDDIN MALANG kelas VIIIE. Penelitian ini bertujuan untuk mengetahui tingkat penalaran matematika siswa berdasarkan jenis kelamin dengan menggunakan soal TIMSS sebagai alat ukur dan dilanjutkan dengan wawancara pada subjek yang terpilih. Subjek dalam penelitian ini ada enam orang, dengan rincian satu orang siswa laki-laki berpenalaran tinggi, satu orang siswa laki-laki berpenalaran sedang, satu orang siswa laki-laki berpenalaran rendah, satu orang siswa perempuan berpenalaran tinggi, satu orang siswa perempuan berpenalaran sedang, satu orang siswa perempuan berpenalaran rendah. Dari hasil penelitian yang didapat secara keselurahan, subjek laki-laki lebih detail dalam memberikan informasi dan mengajukan dugaan. Namun sayangnya, subjek laki-laki kurang jelas dalam memberikan kesimpulan, subjek lebih mengarah ke langsung menjawab tanpa memberikan penjelasan tentang apa yang telah dihasilkan. Berbeda dengan subjek perempuan yang tidak terlalu detail dalam memberikan dugaan, subjek perempuan rata-rata hanya memberikan dua opsi jawaban bahkan satu. Tetapi untuk hal memberikan kesimpulan, subjek perempuan lebih detail dan jelas.
\end{abstract}

Kata Kunci: penalaran, penalaran matematika, jenis kelamin

\begin{abstract}
In mathematics learning, there are three aspects that must be mastered by students, they are aspects of understanding concepts, reasoning, and problem solving. From these three aspects, it can be concluded that in mathematics student must be completely understand about reasoning. In TIMSS, there are also three aspects that students must have in learning mathematics, namely knowing, application (applying), and reasoning (reasoning). From there, it is important to be possessed by students. From that conception, we can conclude that the ability of reasoning must be possessed by student. The ability of reasoning is ability for connect the ideas and arrange in a mathematics argument. For Indonesia student the ability of reasoning it's so weak, its research by TIMSS. The research conducted is descriptive qualitative research. The study was conducted in MALANG SHALAHUDDIN High School in the eighth grade. In this study researchers wanted to know about reasoning abilities based gender using TIMSS questions as a measurement tool and receive interviews with selected subjects. The subjects in this study were six student, with one male student with high level of reasoning, one female student with high level of reasoning, one male student with middle level of reasoning, one female student with middle level of reasoning, one male student with low level of reasoning, one female student with low level of reasoning. Based on the result
\end{abstract}


of the research, it was found that some subjects had high reasoning ability that can completely all the indicator, some subjects had middle reasoning ability that can completely two indicators, and some subjects had low reasoning ability that can completely only one indicator

Keywords: Reasoning, TIMSS, gender

\section{PENDAHULUAN}

Bidang pendidikan secara kusus mendapat perhatian dari berbagai pihak seperti pemerintah, mengingat pendidikan merupakan tombak peningkatan sumber daya manusia dalam daya saing global yang tidak pernah berhenti berkembang. Mengingat pentingnya kualitas pendidikan dalam daya saing global, berbagai pihak secara rutin melakukan evaluasi kepada segala aspek yang berkaitan dengan peningkatan kualitas pendidikan. Hal ini seperti yang dilakukan sebuah lembaga asing yaitu IEA (International Association for the Evaluation of Educational Achievement) lembaga ini mengasesmen kemampuan matematika dan saint siswa dalam evaluasi yang dinamai TIMSS (Trend in International Mathematics amd Science Study). Indonesia mulai bergabung mengikuti evaluasi yang dilakukan oleh TIMSS sejak tahun 1999 pada level SMP. TIMSS dibagi menjadi dua grade, yaitu pada grade empat atau setara dengan kelas empat SD. Dan grade delapan atau setara dengan kelas delapan SMP.

Indonesia berada diposisi bawah pada evaluasi TIMSS yang telah dilakukan, hal ini sangat mengecewakan dan jauh dari memuaskan. Dari total 42 peserta, Indonesia berada pada peringkat ke 38. Karena rendahnya hasil evaluasi yang didapat, perlu diketahui dan dicermati apa penyebab dari rendahnya peingkat siswa Indonesia. Dalam TIMSS disebutkan pula dimensi penilaian secara kognitif yang meliputi tiga aspek yaitu aspek penalaran (reasoning), aspek penerapan (applying), dan aspek pengetahuab atau (knowing). Dalam aspek penalaran (reasoning) siswa dituntut untuk dapat melibatkan kemampuan berlogika dan berpikir sistematis. TIMSS juga pernah meneliti tentang perbedaan penalaran siswa laki-laki dan siswa perempuan. Penalaran dan matemtika merupakan duua hal yang saling berkaitan, materi matematika yang memerlukan penalaran dalam memahi dan penalaran yang memerlukan materi matematika untuk terus berlatih mengasah kemampuan dalam menalar. Penalaran sangat erat kaitannya dengan kehidupan sehari-hari, dalam matematika penalaran juga sangat dibutuhkan. Karena dengan ketrampilan bernalar diharapkan siswa mampu menyelesaikan masalah yang diberikan dengan baik. Hal ini sangat sesuai dengan yang ada pada Kemendikbud tahun 2013 bahwa tujuan dai pembelaran matematika di SMP diantaranya adalah menyaji, mengelola, dan menalar. tingkat penalaran setiap siswa tentunya akan sangat berbeda baik siswa laki-laki dan perempuan.
Menurut Valadine (1999:98) menyatakan hasil tes penalaran atau berpikir logis menunjukan bahwa siswa laki-laki secara signifikan jauh lebih baik dibanding siswa perempuan. Hal ini juga didukung laporan dari NAPLAN (National Assessment Program-Literacy and Numerency) yang menyatakan bahwa siswa laki-laki dalam hal berhitung jauh lebih unggul dari siswa perempuan, dan untuk siswa perempuan secara nyata mengalahkan siswa laki-laki dalam hal tata Bahasa, menulis, mengeja, dan membaca. Hal ini menunjukan adanya keberagaman penalaran matematika siswa laki-laki dan perempuan dalam pembelajaran matematika.

Dengan adanya uraian diatas, maka peneliti tertarik untuk mengungkap bagaimana penalaran matematika siswa SMP dalam menyelesaikan soal TIMSS ditinjau dari jenis kelamin dalam menyelesaikan soal TIMSS.

Tujuan dari penelitian yang dituliskan adalah untuk mendeskripsiskan profil penalaran matematika siswa lakilaki dan siswa perempuan dalam menyelesaikan soal TIMSS.

\section{Penalaran}

Shurter dan Pierce (1966) menyatakan bahwa reasoning atau dalam bahasa Indonsia adalah penalaran, dari fakta dan sumber yang relevan didapat suatu proses pencapaian kesimpulan yang logis. Sedangkan menurut Copi (1990) menyatakan bahwa membuat suatu pernyataan yang baru atau membuat pernyataan, atau suatu kesimpulan, yang berdasarkan pada fakta yang sudah diketahui dan jelas kebenarannya disebut dengan premis. Dari pemaparan ahli diatas, dalam penelitian ini disimpulkan bahwa penalaran adalah hasil atau prodak dari aktivitas mental yang telah menghubungkan gagasan baru, konsep baru, atau informasi untuk membentuk suatu kesimpulan yang dapat dibuktikan kebenaran dan dapat dipertanggung jawabkan kebenarannya.

\section{Penalaran Matematika}

Matematika bukan sekedar cabang ilmu yang mengajarkan anak cara menghitung dengan mahir, tetapi jauh lebih penting dalam itu semua adalah melatih siswa untuk berpikir dan salah satu aspek dalam berpikir adalah bernalar. Siswa akan menggunakan kemampuan bernalarnya untuk menyelesaikan masalah matematika atau pun masalah sehari-hari dengan lebih mudah. Hal ini diharpakan siswa mampu memahami bahwa matematika bukan hanya sekedar angka namun merupakan cabang ilmu yang logis dan masuk akal. Penalaran matematika dapat 
dikatan dalam Bahasa asing dengan sebutan mathematical reasoning. Brodie (2010:7) menyampaikan bahwa mathematical reasoning adalah penalaran mengenai objek matematika. Objek matematika yang dimaksud adalah cabang dari ilmu matematika seperti geometri, aljabar, statistika, dan masih banyak lainnya. Dalam Math Glossary juga dinyatakan bahwa penalaran matematika kemampuan menyelesaikan masalah matemtika secara proses prosedural atau secara matematis dalam memberikan suatu penjelasan atau memberikan alasan secara sistematis. Dalam matematika terdapat dua jenis penalaran, yaitu penalaran induktif dan penalaran deduktif.

\section{Jenis Kelamin}

Secara biologis jenis kelamin mengacu pada perbedaan tubuh antara laki-laki dan perempuan. Seperti yang dikatan oleh Moore dan Sinclaire (1995:117) bahwa perbedaan antara laki-laki dan perempuan disebabkan oleh perbedaan kromosompada janin. Sedangkan merujuk pada pernyataan Santrock (2003:365) yang menyatakan bahwa seks atau jenis kelamin dan gender berbeda dari segi dimensi, dimana istilah seks atau jenis kelamin mengacu pada kondisi biologis laki-laki dan perempua, sedangkan gender mengacu pada kondisi social dan budaya antara laki-laki dan perempuan..

\section{Hubungan Antara Penalaran Matematika dan Jenis Kelamin}

Dari Michael Gurin (2010:129) beberapa pendapat didapatkan bahwa bagian otak kanan laki-laki cenderung lebih unggul dalam angka dan logika dari pada otak kanan perempuan, namun bagian otakkiri perempuan jauh lebih unggul dari otak kiri laki-laki dalam bidang keanggunan estetika dan kereligiusan. Laki-laki dan perempuan juga menunjukan perbedaan dalam hal emosi, berbahasa, seksualitas, kemampuan dalam menyelesaikan soal matematika

Proses benalaran setiap laki-laki sangat berbeda, perbedaan ini dapat dipengaruhi karna strujtur otak dan tingkat hormonal. Perbedaan hormonal antara laki-laki dan perempuan juga menyebabkan perbedaan siswa dalam menalar untuk memahami, dan menganalisis dalam pecahan masalah yang terdapat pada soal matematika.

\section{Profil Penalaran Matematika Siswa}

Profil penalaran matematika siswa merupakan suatu gambaran penalaran yang membahas tentang kecakapan, kemahiran, kesanggupan siswa dalam menyelesaikan soal matematika atau permasalahan matematika yang diberikan. Gambaran dari penalaran matematika dalam penelitian ini akan disuguhkan melalui soal tes TIMSS.

\section{Indikator Penalaran Matematika}

Dalam penelitian ini disuguhkan empat indikator yang menjadi tolak ukur penalaran siswa sebagai berikut.

a. Mengajukan Dugaan

Dalam menyelesaikan masalah dalam soal TIMSS indikator mengajukan dugaan ini dapat terlihat ketika siswa mampu menduga bagaimana proses penyelesaian dari permasalahan yang diberikan. Serta dapat menduga berapa jawaban yang mungkin ada.

b. Memberikan penjelasan dengan model, fakta, sifat- sifat dan hubungan.

Dalam indikator memberikan penjelasan dengan model, fakta, sifat- sifat dan hubungan dapat dilihat dari cara siswa menyelesaikan masalah yang diberikan. Ketika siswa mampu memberikan penjelasan langkah-langkah penyelesaian dengan konsep-konsep yang ada dan benar.

c. Melakukan manipulasi matematika

Dalam indikator melakukan manipulasi matematika adalah hal yang sangat dibutuhkan ketika siswa akan menyelesaikan masalah matematika. Pada saat siswa telah mampu mengubah masalah yang diberikan ke dalam bentuk matematika, dan mampu menyelesaikannya dengan operasi matematika yang benar makan dia sudah mencapai indikator melakukan manipulasi matematika.

d. Menarik kesimpulan, menyusun bukti, memberikan alasan atau bukti terhadap beberapa solusi

Dalam indikator menarik kesimpulan, menyusun bukti, memberikan alasan atau bukti terhadap beberapa solusi akan muncul pada saat siswa mampu membuat kesimpulan mengenai masalah yang diberikan dan mampu memberikan solusi lain serta menjelaskan alasan atau bukti adanya solusi lain.

\section{METODE}

Penelitian yang dilakukan adalah penelitian deskriptif kualitatif. Penelitian dilakukan di SMP SHALAHUDDIN MALANG dikelas VIII. Penelitian ini bertujuan untuk mengetahui tingkat penalaran matematika siswa berdasarkan jenis kelamin dengan menggunakan soal TIMSS sebagai alat ukur dan dilanjutkan dengan wawancara pada subjek yang terpilih. Subjek dalam penelitian ini ada enam orang, dengan rincian satu orang siswa laki-laki berkemampuan penalaran tinggi, satu orang siswa laki-laki berkemampuan penalaran sedang, satu orang siswa laki-laki berkemampuan penalaran rendah, satu orang siswi perempuan berkemampuan penalaran tinggi, satu orang siswi perempuan 
berkemampuan penalaran sedang, satu orang siswi perempuan berkemampuan penalaran rendah.

Peneliti memilih instrumen yang digunakan dalam penelitian ini berupa soal tes TIMSS dan pedoman wawancara. Soal tes yang digunakan adalah soal tes model TIMSS. Tes ini digunakan dengan tujuan untuk mengetahui penalaran matematika siswa dan mencari subjek penelitian yang sesuai untuk penelitian peneliti yang kemudian dilakukan analisa lebih lanjut untuk mengetahui penalaran matematika siswa laki - laki dan perempuan

Analisis data yang dilakukan dalam penelitian ini adalam menganalisis hasil tes dan hasil wawancara yang telah dilakukan.

Dalam penelitian ini menganalisis data dengan menggunakan uji Korelasi Product Moment Pearson untuk menyatakan ada atau tidaknya hubungan antara variabel $X$ dengan variabel $Y$. Sebelum menganalisis data menggunakan uji korelasi, angket perlu diuji validitas dan realibilitas terlebih dahulu. Teknik analisis data pada penelitian ini sebagai berikut :

Langkah-langkah untuk menganalisis hasil tes penalaran matematika siswa adalah sebagai berikut.

a. Mengoreksi hasil tes penalaran matematika yang telah dikerjakan oleh siswa.

b. Menghitung indikator yang telah dicapai oleh siswa.

c. Mengategorikan hasil tes siswa berdasarkan tiga variasi, yaitu penalaran matematika tinggi, penalaran matematika sedang, dan penalaran matematika rendah berdasarkan nilai yang dicapai siswa dengan catatan pengelompokan siswa disetiap variasi tidak terpaut terlalu jauh perolehan hasilnya.

\begin{tabular}{|c|c|}
\hline $\begin{array}{c}\text { Kategori } \\
\text { Kemampuan } \\
\text { Matematika }\end{array}$ & Indikator Yang Dicapai \\
\hline $\begin{array}{c}\text { Penalaran } \\
\text { matematika } \\
\text { Tinggi }\end{array}$ & $\begin{array}{c}\text { Memenuhi 4 indikator } \\
\text { yang telah ditetapkan }\end{array}$ \\
\hline Penalaran & Memenuhi minimal 2 \\
matematika & indikator yang telah \\
Sedang & ditetapkan \\
\hline Penalaran & $\begin{array}{c}\text { Memenuhi maksimal 1 } \\
\text { indikator yang telah } \\
\text { ditematika } \\
\text { Rendah }\end{array}$ \\
\hline
\end{tabular}

Tabel 1. Pengelompokan Variasi Hasil TesPenalaran matematika

\section{Hasil Dan Pembahasan}

Tes penalaran matematika siswa diberikan dalam satu butir soal yang telah mencakup kriteria yang telah ditentukan sebelumnya. Soal yang diberikan merupakan soal TIMSS yang sebelumnya telah diujikan pada TIMSS $20118^{\text {th }}$ - Grade Mathematics Concept and Mathematics Items dengan materi geometri dan harus diselesaikan dalam waktu 30 menit dikerjakan secara individu dengan memberikan jawaban sedetail mungkin.

Table 1 Hasil Tes Penalaran matematika Siswa

\begin{tabular}{|c|c|c|c|c|}
\hline No. & Nama & $\begin{array}{c}\text { Jenis } \\
\text { Kelamin }\end{array}$ & $\begin{array}{c}\text { Nilai } \\
\text { Skala } \\
100 \\
\end{array}$ & $\begin{array}{c}\text { Kemampuan } \\
\text { Matematika }\end{array}$ \\
\hline 1. & $\mathrm{ABM}$ & Laki-laki & 65 & Sedang \\
\hline 2. & AYN & Laki-laki & 30 & Rendah \\
\hline 3. & $\mathrm{ACN}$ & Laki-laki & 65 & Tinggi \\
\hline 4. & ARS & Perempuan & 65 & Sedang \\
\hline 5. & AN & Perempuan & 30 & Rendah \\
\hline 6. & AMS & Perempuan & 95 & Tinggi \\
\hline 9. & EP & Perempuan & 75 & Sedang \\
\hline 7. & ASC & Perempuan & 50 & Sedang \\
\hline 8. & DAA & Laki-laki & 90 & Tinggi \\
\hline 10. & GID & Laki-laki & 20 & Rendah \\
\hline 11. & $\mathrm{KA}$ & Perempuan & 25 & Rendah \\
\hline 12. & KAA & Laki-laki & 50 & Sedang \\
\hline 13. & MFR & Laki-laki & 20 & Rendah \\
\hline 14. & MRB & Laki-laki & 20 & Rendah \\
\hline 15. & MAA & Laki-laki & 20 & Rendah \\
\hline 16. & MHA & Laki-laki & 20 & Rendah \\
\hline 17. & ND & Laki-laki & 20 & Rendah \\
\hline No. & Nama & $\begin{array}{c}\text { Jenis } \\
\text { Kelamin }\end{array}$ & $\begin{array}{c}\text { Nilai } \\
\text { Skala } \\
\mathbf{1 0 0} \\
\end{array}$ & $\begin{array}{c}\text { Kemampuan } \\
\text { Matematika }\end{array}$ \\
\hline 18. & NFM & Perempuan & 50 & Sedang \\
\hline 19. & NK & Perempuan & 40 & Rendah \\
\hline 20. & $\mathrm{PA}$ & Perempuan & 30 & Rendah \\
\hline 21. & RTM & Laki-laki & 50 & Sedang \\
\hline 22. & RAF & Laki-laki & 35 & Rendah \\
\hline 23. & RRF & Perempuan & 80 & Tinggi \\
\hline 24. & $\mathrm{~S}$ & Laki-laki & 30 & Rendah \\
\hline 25. & TNS & Perempuan & 60 & Sedang \\
\hline 26. & SAG & Laki-laki & 95 & Tinggi \\
\hline 27. & SV & Perempuan & 60 & Sedang \\
\hline 28. & VAD & Laki-laki & 20 & Rendah \\
\hline 29. & JAP & Laki-laki & 20 & Rendah \\
\hline
\end{tabular}

Berdasarkan Tabel 2 yang telah disajikan tentang hasil tes penalaran matematika siswa dalam menyelesaikan soal TIMSS, maka dipilihlah enam orang siswa sebagai subjek yang dipilih untuk dilanjutkan tes wawancara. Enam orang siswa yang dipilih adalah satu orang siswa laki-laki dan satu siswa perempuan berpenalaran matematika tinggi, satu orang siswa laki-laki dan satu siswa perempuan berpenalaran matematika sedang, serta satu orang siswa laki-laki dan satu siswa perempuan berpenalaran matematika rendah. Pada pengambilan subjek yang telah dilakukan, siswa laki-laki dan perempuan yang terpilih memiliki penalaran matematika tinggi, sedang, serta rendah memiliki perbedaan skor yang tidak signifikan disetiap kategorinya, supaya dapat dilihat kemampuan komunikasi siswa dengan kemampuan yang sama namun memiliki jenis kelamin yang berbeda. Adapun subjek 
penelitian yang telah didapatkan adalah sebagai berikut dalam table 4.3

Table 3 Subjek Penelitian Terpilih

\begin{tabular}{|c|c|c|c|c|}
\hline No. & Nama & $\begin{array}{c}\text { Jenis } \\
\text { Kelamin }\end{array}$ & $\begin{array}{c}\text { Nilai } \\
\text { Skala } \\
\mathbf{1 0 0}\end{array}$ & $\begin{array}{c}\text { Kemampuan } \\
\text { Matematika }\end{array}$ \\
\hline 1. & DAA & Laki-laki & 90 & Tinggi \\
\hline 2. & AMS & Perempuan & 95 & Tinggi \\
\hline 3. & ACN & Laki-laki & 65 & Sedang \\
\hline 4. & ARS & Perempuan & 65 & Sedang \\
\hline 5. & AYN & Laki-laki & 30 & Rendah \\
\hline 6. & GID & Perempuan & 20 & Rendah \\
\hline
\end{tabular}

Setelah terpilih enam subjek, tahap selanjutnya adalah tahap wawancara dengan tujuan memperjelas dan memperoleh penjelasan mengenai jawaban siswa, sehingga akan muncul penalaran matematika yang dimaksudkan., hasil dari tes penalaran matematika siswa secara tertulis, dilambangkan dengan kode- kode seperti pada table berikut ini.

Table 4 Kode Penyajian Hasil Tes Penalaran matematika Siswa

\begin{tabular}{|c|c|}
\hline Kode & Keterangan \\
\hline SLPM $x$ 0 $i-T$ & $\begin{array}{c}\text { Jawaban subjek laki-laki } \\
\text { kemampuan matematika } x \\
\text { dengan urutan ke }-i \text { secara } \\
\text { tertulis }\end{array}$ \\
\hline SPPM $x$ 0 $i-T$ & $\begin{array}{c}\text { Jawaban subjek laki-laki } \\
\text { kemampuan matematika } x \\
\text { dengan urutan ke - } i \text { secara } \\
\text { tertulis }\end{array}$ \\
\hline
\end{tabular}

Table 5 Kode Penyajian Transkip Wawancara

\begin{tabular}{|c|c|}
\hline Kode & Keterangan \\
\hline $\mathrm{P}-0 i$ & $\begin{array}{l}\text { Pertanyaan ke }-i \text { yang diberikan } \\
\text { peneliti }\end{array}$ \\
\hline SKM $x-0 i$ & $\begin{array}{l}\text { Jawaban subjek laki-laki } \\
\text { penalaran } \\
\text { terhadap pertanyaan peneliti ke } \\
-i\end{array}$ \\
\hline SPKM $x-0 i$ & $\begin{array}{l}\text { Jawaban subjek permpuan } \\
\text { penalaran } \\
\text { terhadap pertanyaan peneliti ke } \\
-i\end{array}$ \\
\hline
\end{tabular}

Dan didapat hasil sebagai berikut :

1. Hasil dan Analisis Data Penalaran matematika Siswa Subjek Laki-Laki Penalaran matematika Tinggi (SLPMT) dalam menyelesaikan soal TIMSS

Subjek SLPMT menuliskan dugaan yang terdapat pada soal yang telah diberikan (SLPMT $01 \mathrm{~T}$ ). Subjek SLPMT menuliskan penjelasan dengan model, fakta, sifat-sifat, serta hubungan yang mungkin terjadi pada setiap jawaban (SLPMT 02 T). Subjek SLPMT melakukan manipulasi matematika (SLPMT $03 \mathrm{~T}$ ). Subjek SLPMT melakukan penarikan kesimpulan, menyusun bukti, memberikan alasan atau bukti terhadap beberapa solusi seperti yang nampak pada (SLPMT $04 \mathrm{~T}$ ).

Dalam wawancara diatas dapat disimpulkan bahwa siswa memberikan dugaan dengan mencoba-coba posisi buku. Subjek juga menggambarkan posisi buku dengan ilustrasi gambar sehingga nampak jelas maksud dari jawaban subjek. Subjek juga mengelola informasi dengan baik, subjek menggunakan informasi untuk membuat ideide baru dengan membandingkan panjang box dan panjang buku, lebar box dengan lebar buku, serta tinggi box dengan tinggi buku.

2. Hasil dan Analisis Data Penalaran Matematika Siswa Subjek Laki-Laki Penalaran Matematika Sedang (SLPMS) dalam menyelesaikan soal TIMSS

Subjek SLPMS menuliskan dugaan yang terdapat pada soal yang telah diberikan (SLPMS 01 T). Subjek SLPMS menuliskan penjelasan dengan model, fakta, sifat-sifat, serta hubungan yang mungkin terjadi pada setiap jawaban (SLPMT 02 T). Subjek SLPMS melakukan manipulasi matematika (SLPMS 03 T) dengan cara menyandingkan panjang, lebar, dan tinggi masingmasing benda sehingga nampak jelas perbandingannya. Subjek SLPMS tidak melakukan penarikan kesimpulan secara sempurna, namun SLPMS melakukan penyusunan bukti, memberikan beberapa solusi seperti yang nampak pada (SLPMS $04 \mathrm{~T}$ ).

Dalam wawancara diatas dapat disimpulkan bahwa siswa subjek mengelola informasi dengan baik, subjek menggunakan informasi untuk membuat ide-ide baru dengan membandingkan panjang box dan panjang buku, lebar box dengan lebar buku, serta tinggi box dengan tinggi buku.

3. Hasil dan Analisis Data Penalaran matematika Siswa Subjek Laki-Laki Penalaran matematika Rendah (SLPMR) dalam menyelesaikan soal TIMSS.

Pada subjek SLPMR menuliskan dugaan yang terdapat pada soal yang telah diberikan (SLPMR 01 T). Subjek SLPMR menuliskan penjelasan dengan model, fakta, sifat-sifat, serta hubungan yang mungkin terjadi pada jawaban (SLPMR 02 T). Subjek SLPMR melakukan manipulasi matematika (SLPMR $03 \mathrm{~T}$ ) dengan cara menyandingkan panjang, lebar, dan tinggi masing-masing benda 
sehingga nampak jelas perbandingannya. Tidak terdapat kesimpulan dan bukti bagaimana jawaban itu didapatkan dalam lembar jawaban siswa.

Dalam wawancara dapat disimpulkan bahwa siswa memberikan dugaan dengan mencoba-coba posisi buku, subjek mencoba satu persatu posisi yang dimungkinkan bisa di gunakan kedalam box, ada posisi di berdirikan dan ditidurkan dimana masing-masing posisi buku disandingkan dengan box. Subjek juga memberikan simpulan akhir namun kurang jelas dan hanya dituliskan jumlah dari hasil penghitungan saja.

4. Hasil dan Analisis Data Penalaran matematika Siswa Subjek Perempuan Penalaran matematika Tinggi (SPPMT) dalam menyelesaikan soal TIMSS

Pada subjek SPPMT menuliskan dugaan yang terdapat pada soal yang telah diberikan (SPPMT 01 T). Subjek SPPMT menuliskan penjelasan dengan model, fakta, sifat-sifat, serta hubungan yang mungkin terjadi pada setiap jawaban (SPPMT 02 T). Subjek SPPMT melakukan manipulasi matematika (SPPMT 03 T) dengan cara menyandingkan panjang, lebar, dan tinggi masingmasing benda sehingga nampak jelas perbandingannya. Subjek SPPMT melakukan penarikan kesimpulan, menyusun bukti, memberikan alasan atau bukti terhadap beberapa solusi seperti yang nampak pada (SPPMT $04 \mathrm{~T}$ ).

Dalam wawancara disimpulkan bahwa Subjek menggunakan informasi untuk membuat ide-ide baru dengan membandingkan panjang box dan panjang buku, lebar box dengan lebar buku, serta tinggi box dengan tinggi buku. Setelah subjek membandingkan, subjek membagi panjang box dengan panjang buku dan diperoleh jawaban dengan pembulatan terkecil namun tidak dijelaskan alasan mengapa harus dibulatkan pada pembulatan terkecil, hal ini nampak jelas pada sesi wawancara. Subjek juga memberikan simpulan akhir namun kurang jelas dan hanya dituliskan jumlah dari hasil penghitungan saja tanpa penjelasan lebih lengkap.

5. Hasil dan Analisis Data Penalaran matematika Siswa Subjek Perempuan Penalaran matematika Sedang (SPPMS) dalam menyelesaikan soal TIMSS

Pada subjek SPPMS menuliskan dugaan yang terdapat pada soal yang telah diberikan (SPPMS 01 T).Subjek SPPMS menuliskan penjelasan dengan model, fakta, sifat-sifat, serta hubungan yang mungkin terjadi pada setiap jawaban (SPPMS 02 T). subjek SLPMS melakukan manipulasi matematika (SLPMS $03 \quad \mathrm{~T}$ ) dengan cara menyandingkan panjang, lebar, dan tinggi masingmasing benda sehingga nampak jelas perbandingannya. Subjek SPPMS melakukan penarikan kesimpulan, SLPMS melakukan penyusunan bukti, memberikan beberapa solusi seperti yang nampak pada (SLPMS 04 T).

Dalam wawancara subjek juga menggambarkan posisi buku dengan ilustrasi gambar sehingga nampak jelas maksud dari jawaban subjek. Subjek juga mengelola informasi dengan baik, subjek menggunakan informasi untuk membuat ide-ide baru dengan membandingkan panjang box dan panjang buku, lebar box dengan lebar buku, serta tinggi box dengan tinggi buku. Setelah subjek membandingkan, subjek membagi panjang box dengan panjang buku dan diperoleh jawaban dengan pembulatan terkecil namun tidak dijelaskan alasan mengapa harus dibulatkan pada pembulatan terkecil, hal ini nampak jelas pada sesi wawancara. Subjek juga memberikan simpulan akhir namun kurang jelas dan hanya dituliskan jumlah dari hasil penghitungan saja tanpa penjelasan lebih lengkap.

6. Hasil dan Analisis Data Penalaran Matematika Siswa Subjek Perempuan Penalaran Matematika Rendah (SPPMR) dalam menyelesaikan soal TIMSS

Dalam lembar penyelesaian nampak jelas bahwa SPPMR memberikan penjelasan berupa model gambar namun krang jelas dan tidak terdapat keterangan, juga tidak ada informasi mengenai fakta, sifat-sifat dan hubungan. Subjek hanya menuliskan volume buku dan box. Dalam lembar penyelesaian nampak jelas bahwa SPPMR tidak melakukan manipulasi matematika.

Dalam lembar penyelesaian nampak jelas bahwa SPPMR memberikan kesimpulan sederhana tentang hasil akhir yang didapat. Namun tidak memberikan bukti, alasan atau pilihan beberapa solusi yang mungkin ada. Dalam sesi wawancara subjek memberikan penjelasan tentang pengajuan dugaan, manipulasi matematika, menghubungkan antara volume kedua benda dan memberikan kesimulan. Namun hal tersebut sangat kurang dan terlihat samar.

\section{PENUTUP}

\section{Simpulan}


Dari penjelasan diatas dapat disimpulkan bahwa siswa laki-laki mempunyai kecenderungan menjawab soal dengan detail dan memberikan informasi secara jelas, siswa laki-laki juga lebih memberikan dugaan jawaban, namun masih kurang memberikan kesimpulan pada soal yang diberikan.

Untuk siswa perempuan dapat disimpulkan bahwa siswa perempuan mempunyai kecenderungan memberikan dugaan lebih sedikit dari siswa laki-laki. Namun cukup lengkap mmberikan informasi, namun jelas memberikan kesimpulan yang dibutuhkan.

Hal ini disebabkan karena kurangya siswa berlatih menyelesaikan soal-soal penalaran TIMSS, yang memang sangat jarang diberikan oleh guru disekolah.

Secara keselurahan, subjek laki-laki lebih detail dalam memberikan informasi dan mengajukan dugaan. Sangat terlihat jelas dalam kedua hal tersebut. Subjek juga cenderung mendukung dugaan yang dimaksud dengan memberikan ilustrasi yang menggambarkan situasi yang diinginkan. Namun sayangnya, subjek laki-laki kurang jelas dalam memberikan kesimpulan, subjek lebih mengarah ke langsung menjawab tanpa memberikan penjelasan tentang apa yang dicapai.

\section{Saran}

Berdasarkan hasil penelitian yang telah dilakukan, maka peneliti memberikan saran sebagai berikut.

1. Pada hasil penelitian, terlihat subjek cenderung kurang dalam hal mengekspolrasi kemungkinan jawaban yang ada. Subjek cenderung puas hanya dengan satu jawaban, sehingga kurang terlihat adanya penalaran yang dilakukan oleh subjek. Subjek juga belum mengeksplorasi informasi dan fakta yang terdapat dalam soal secara detail dan jelas. Dalam hal manipulasi pun masih terdapat banyak subjek yang hanya melakukan sekali manipulasi. Begitu pula dengan tahap penarikan kesimpulan yang dirasa masih kurang.
2. Bagi peneliti selanjutnya yang akan meneliti tentang penalaran matematika, perlu dilakukan pembahasan lebih mendalam mengenai penalaran matematika dengan subjek yang lebih banyak.

\section{DAFTAR PUSTAKA}

Brodie, Karin. 2010. Teaching Mathematical Reasoning in Secondary School. Classroom. New York: Springer

Depdiknas. 2004. Peraturan Dirjen Didasmen No. 506/C/PP/2004 tanggal 11 November 2004 Tentang Penilaian Perkembangan Anak Didik Sekolah Menangah Pertama (SMP). Jakarta: Dirjen Dikdasmen Depdiknas

Gurian, Michael. (2010). Boys and Girls Learn Differently: A Guide For Teachers and Parents. San Fransisco : Jossey-Bass.

International Association for the Evaluation of Educational Achievement.2013. Trends in International Mathematics And Science Study (TIMSS) 2011 Grade 8 Mathematics Assessment Items.

(https://erikvalentinomath.files.wordpress.com/2015/0 4/timss2011_g8 math.pdf, diakses pada 9 0ktober 2018)

Keraf, G. (2007). Argumentasi dan Narasi. Jakarta: PT Gramedia Pustaka Utama.

Robbins, S. P., dan Judge, T. A., 2009. Organizational Behavior. $13^{\text {th }}$ Edition. Pearson Education, Inc., Upper Saddle River, New Jersey.

Santrock, John W. (2003). Adolescense perkembangan remaja. Edisi Keenam. Alih Bahasa: Dra. Shinto B. Adelar, M.Sc. Jakarta: Erlangga

Spelke, E. (2005). "Sex Differences in Intrinsic Aptitude for Mathematics and Science". American Psychologist. 